\title{
A new Brevibacterium sp. isolated from infected genital hair of patients with white piedra
}

\author{
M. E. McBRIDE, K. M. ELLNER†, H. S. BLACK*, J. E. CLARRIDGE* and J. E. WOLF \\ Department of Dermatology, Baylor College of Medicine, One Baylor Plaza, Houston, Texas 77030, \\ *Veterans Administration Medical Center, Houston, Texas 77030 and $†$ Kaiser Permanente, 3355 Lennox Road, \\ N.D. Suite 1000, Atlanta, Georgia 30326, USA
}

\begin{abstract}
Summary. A new aerobic gram-positive non-sporeforming bacillus has been isolated from infected genital hair of patients with white piedra in association with Trichosporon beigelii. This species has been characterised morphologically, nutritionally, by DNA base composition, cell-wall analysis and cellular fatty-acid profile on the basis of 14 isolates. The $\mathrm{G}+\mathrm{C}$ content of DNA is $63.05 \mathrm{~mol} \%$. Cell walls possess meso-diaminopimelic acid (Type IV) and the sugars glucose, galactose, xylose and ribose; mycolic acids are not present. The species has a distinct colonial and microscopic morphology, is strongly proteolytic and produces methanethiol. These findings and the cellular fatty-acid profile are compatible with the genus Brevibacterium. A new species is proposed based on the following characters: colonial and microscopic growth and morphology; conditions for rod-to-coccus cycle; ribose utilisation; and tellurite reduction. The type strain has been named Brevibacterium mcbrellneri E2cr (ATCC 49030). The strong proteolytic properties may be the mechanism of pathogenesis.
\end{abstract}

\section{Introduction}

In a previous study of genital white piedra, ${ }^{1}$ grampositive rods were observed histologically in hair lesions and infected hair. A morphologically and biochemically distinct bacterium was isolated frequently with the yeast Trichosporon beigelii, and synergic growth was demonstrated between the two organisms in vitro. ${ }^{2}$ The possibility that this bacterium may play a role in the pathogenesis of white piedra indicated the importance of its characterisation and of establishing its taxonomic position.

Aerobic non-sporeforming gram-positive rods are ubiquitous in nature and are particularly prevalent as part of the normal flora on human skin, where they are commonly designated as coryneform bacteria. Advances in chemotaxonomic methods, which include identification of cell-wall peptidoglycan, sugars and mycolic acids, whole cell fatty-acid composition, and polar lipid and menaquinone patterns, have provided a basis for differentiation of these organisms. ${ }^{3}$ From these methods and by morphology, species previously designated as coryneforms can now be assigned to other genera:4 Arthrobacter, Cellulomonas, Clavibacter, Brevibacterium, Corynebacterium, Curtobacterium, Gordena, Microbacterium, Rhodococcus. However, when dealing with environmental strains, unless an organism has become clinically relevant,

Received 3 March 1992; revised version received 9 Feb. 1993; accepted 13 Feb. 1993. most species have remained unnamed..$^{5}$ Even most clinical isolates, many of which are asymptomatic colonisers or part of the normal flora, defy classification. ${ }^{5}$ Pitcher ${ }^{6}$ recognised that many skin isolates of coryneform morphology belong to the genus Brevibacterium. The distinction between Corynebacterium and Brevibacterium can be made morphologically, nutritionally, by chemotaxonomic markers of the cell walls and by the production of methanethiol. ${ }^{7}$

The purpose of this study was to characterise these isolates from infected hair of patients with white piedra morphologically, nutritionally, by DNA base composition, cell-wall analysis, and fatty-acid profiles. These gram-positive non-sporeforming rods were compared with culture collection strains of Corynebacterium and Brevibacterium spp. to establish their taxonomic position and learn more of their pathogenic potential.

\section{Materials and methods}

\section{Micro-organisms}

Fourteen strains of coryneform bacteria were isolated from hair nodules from nine patients with white piedra in a previous study, ${ }^{1}$ as previously described. Briefly, genital hairs from patients with nodules were surface sterilised by rinsing in alcohol $70 \%$ for $1 \mathrm{~s}$ and then soaked overnight in phosphate-buffered saline, $\mathrm{pH} 7 \cdot 2$, containing Triton X100 $0.1 \%$. The nodules 
Table I. Reference strains

\begin{tabular}{lrl}
\hline Species & Designation & Source \\
\hline Corynebacterium diphtheriae & 160 & VAMC \\
C. pseudotuberculosis & 1121 & VAMC \\
C. renale & 19412 & ATCC \\
C. jeikeium & 162 & VAMC \\
C. pilosum & 29592 & ATCC \\
Rhodococcus equi & 4 & VAMC \\
Brevibacterium epidermidis & 35514 & ATCC \\
& & type strain \\
Brevibacterium linens & 9172 & ATCC \\
\hline
\end{tabular}

VAMC, Veterans Administration Medical Center, Houston. ATCC, American Type Culture Collection.

were removed from the hair by scraping with a scalpel, then macerated with dissecting needles. The resulting suspension was inoculated on to Casman's Sheep Blood Agar (Difco) and incubated at $35-37^{\circ} \mathrm{C}$ for 5 days. Isolates were compared with culture collection strains of Corynebacterium and Brevibacterium spp. (table I) which represented type strains of the two genera chosen or were strains that resembled the unknown clinical isolates. Isolates were subcultured on Casman's sheep blood agar, suspended in Trypticase Soy Broth (Difco) with glycerol 20\%, and stored at $-70^{\circ} \mathrm{C}$.

\section{Morphological studies}

Isolates were grown on Casman's sheep blood agar, Trypticase Soy Agar (Difco; TSA), Czapek's Mineral Agar (Difco) with yeast extract $0.2 \%$ (CYA) and Yeast Malt Agar (Difco: YMA). Microscopic and colonial morphology were observed during incubation for 2 weeks at 25,30 and $35^{\circ} \mathrm{C}$. Modified Kinyoun $\operatorname{stain}^{8}$ was used to test for acid fastness. Anaerobic growth was tested in an anaerobic jar with the Gaspak System (BBL).

\section{Biochemical tests}

All Brevibacterium spp. except $B$. linens strains were tested for effect on the following substrates by standard methods $^{9}$ and in the API 20E system (API bioMérieux Inc., La Balones les Grottes, France). API Coryne and API Rapid ANA were used to test three piedra strains, $B$. epidermidis and B. linens. The API Coryne strip, when used conventionally according to the manufacturers' instructions, does not differentiate among the Brevibacterium spp. The tests for nitrate reductase, pyrazinamidase, pyrrolidonylarylamidase, alkaline phosphatase, $\beta$-glucuronidase and acetyl- $\beta$-glucosaminidase were read after incubation for $24 \mathrm{~h}$, according to the instructions, but the tests for aesculin, urea and gelatin hydrolysis and fermentation of ribose, xylose, mannitol, maltose, lactose, sucrose and glycogen were held for 7 days at $35^{\circ} \mathrm{C}$ in air. The Rapid ANA II system test for pre-formed enzymes was used according to the manufacturers' instructions. It includes the following biochemical tests: hydrolysis of urea, aryl substituted arabinoside, galactoside, glucoside, sucroside, glucosaminide and phosphate; hydrolysis of leucyl-glycine, glycine, proline, phenylalanine, arginine, serine and pyrrolidonyl; and formation of indole. The effects of the test strains on starch, casein, tyrosine and xanthine were tested on commercially prepared plates (Scott, Fiskeville, RI 02823, USA). Litmus milk activity was tested on litmus-milkagar plates. ${ }^{10}$ Hydrolysis of Tween 80 was tested on TSA containing Tween $800 \cdot 1 \%$. Methanethiol production was detected by the method of Pitcher and Malnick, ${ }^{6}$ and Laakso, as described by Jones and Keddie. ${ }^{7}$ Tolerance to $\mathrm{NaCl} 6.5 \%, 10 \%, 15 \%$ and $20 \%$ was tested in TSA. Reduction of tellurite was tested on Bacto Tellurite Medium (Difco).

\section{Antibiotic susceptibility tests}

These were done by the Kirby Bauer disk diffusion method $^{11}$ on Mueller Hinton agar with the following antibiotic disks: penicillin $2 \mu \mathrm{g}$, ampicillin $10 \mu \mathrm{g}$, erythromycin $15 \mu \mathrm{g}$, tetracycline $30 \mu \mathrm{g}$, methicillin $5 \mu \mathrm{g}$, oxacillin $10 \mu \mathrm{g}$, vancomycin $15 \mu \mathrm{g}$, cephalothin $30 \mu \mathrm{g}$, ciprofloxacin $5 \mu \mathrm{g}$, gentamicin $10 \mu \mathrm{g}$ and trimethoprim sulphate $24 \mu \mathrm{g}$. Sensitivity to ergosan was tested by inoculation on TSA containing ergosan $0 \cdot 1 \%$.

\section{Cellular fatty-acid analysis}

Three representative strains of the new organism were tested by Microbial ID Inc. (Newark, Delaware, USA) with the Hewlett-Packard System as previously described. ${ }^{12}$ Biomass was obtained by growth on TSA at $25^{\circ} \mathrm{C}$.

\section{Cell-wall analysis}

Six strains of the new species that demonstrated characteristic colonial and microscopic morphology were chosen for cell-wall analysis. These and reference strains were grown on Casman's sheep blood agar at $37^{\circ} \mathrm{C}$. Culture collection strains of Corynebacterium spp. and B. epidermidis were incubated overnight and the six new isolates for 3 days. A heavy suspension of the growth was made in saline $0.85 \%$ and $0.2 \mathrm{ml}$ was inoculated on to Brain Heart Infusion Agar (Difco). When maximum growth was achieved, plates were flooded with formalin $10 \%$ and left overnight. The suspension of organisms was centrifuged and the bacteria were washed twice with distilled water and once with alcohol $95 \%$ then allowed to dry in a vacuum desiccator and stored at $-70^{\circ} \mathrm{C}$.

\section{Carbohydrate analysis}

Biomass was prepared as described above for cellwall analysis. Methods of analysis for cellular carbohydrates were similar to those described previously. ${ }^{13}$ 
Cells (50 mg dry weight) were hydrolysed for $4 \mathrm{~h}$ in $1.5 \mathrm{ml}$ of concentrated $\mathrm{H}_{2} \mathrm{SO}_{4}$ in tightly sealed reactivials at $100^{\circ} \mathrm{C}$. After cooling, the $\mathrm{pH}$ was adjusted to 5.2-5.5 with saturated $\mathrm{BaOH}$. The digest was centrifuged $(1000 \mathrm{~g}$ for $10 \mathrm{~min})$ and the supernate was evaporated to dryness under a stream of air. The residue was redissolved in $0.5 \mathrm{ml}$ of distilled water and 2-4 $\mu \mathrm{l}$ was spotted on Kodak 13255 Cellulose Chromatogram sheets. The $20 \times 20 \mathrm{~cm}$ sheets were predeveloped and activated before use. Chromatograms were developed for $2 \mathrm{~h}$ with acetone:methanol: chloroform:water, 80:10:10:5 v:v:v:v. The sheets were then sprayed with 1,3-dihydroxynaphthalene ethanolic solution $(20 \mathrm{mg} / 20 \mathrm{ml}$ of ethanol) containing concentrated $\mathrm{H}_{2} \mathrm{SO}_{4} 1 \%$ and placed in an oven for $10 \mathrm{~min}$ at $100^{\circ} \mathrm{C}$. Standards used were ribose, galactose, arabinose and xylose.

\section{Mycolic acid esters}

Biomass was prepared as described above for cellwall analysis. With slight modification, whole cell methanolysates were prepared according to the methods of Goodfellow et al. ${ }^{14} ; 100 \mathrm{mg}$ of dry cells were methanolysed for $16 \mathrm{~h}$ at $50^{\circ} \mathrm{C}$ in 20 -ml teflonlined screw-top tubes containing methanol $5 \mathrm{ml}$, toluene $5 \mathrm{ml}$ and concentrated $\mathrm{H}_{2} \mathrm{SO}_{4} 0.2 \mathrm{ml}$. The mixture was cooled to room temperature and extracted twice with $2 \mathrm{ml}$ of hexane; the upper phase was removed, dried under $\mathrm{N}_{2}$, and reconstituted in $1 \mathrm{ml}$ of hexane for analysis. For each sample, $5 \mu \mathrm{l}$ was spotted on HPTLC Silica Gel 60 plates which were predeveloped and activated before use. Chromatograms were first developed in a petroleum ether (b.p. $30-60^{\circ} \mathrm{C}$ ): diethyl ether $85: 15 \mathrm{v}: \mathrm{v}$ solvent. Mycolic esters were visualised by spraying the plates with chromic acid solution and charring at $200^{\circ} \mathrm{C}$. Separation of mycolic esters from fatty acids of lower mol. wt was verified by co-chromatography with fatty acid methyl ester standards, reversibly detecting the components with iodine vapour and re-developing the chromatogram in methanol: water $75: 30 \mathrm{v}: \mathrm{v}$ for $6 \mathrm{~h}$.

\section{Diaminopimelic acid analysis}

The method was adapted from that of Staneck and Roberts. ${ }^{15}$ Dried cells $(100 \mathrm{mg}$ ) were hydrolysed with $1 \mathrm{ml}$ of $6 \mathrm{~N} \mathrm{HCl}$ for $18-22 \mathrm{~h}$ at $100^{\circ} \mathrm{C}$ in teflon-lined screw-topped tubes on a heat block. The material was filtered through Whatman No.1 filter paper, washed with $1 \mathrm{ml}$ of $6 \mathrm{~N} \mathrm{HCl}$ and dried in glass culture plates in a fume hood. The residue was dissolved in $0.5 \mathrm{ml}$ of distilled water for chromatography on Eastman Kodak No. 6064 cellulose which was pre-developed in a thin layer chromatography tank with methanol: water:6 $\mathrm{N} \mathrm{HCl}$ :pyridine $80: 26: 4: 10 \mathrm{v}: \mathrm{v}: \mathrm{v}: \mathrm{v}$. The plate was activated at $100^{\circ} \mathrm{C}$ and $3-5-\mu l$ samples were spotted and developed for $c .4 \mathrm{~h}$ in methanol: water: $10 \mathrm{~N} \mathrm{HCl}$ :pyridine, $80: 17 \cdot 5: 2 \cdot 5: 10 \mathrm{v}: \mathrm{v}: \mathrm{v}: \mathrm{v}$. Diaminopimelic acid (DAP) was visualised by spraying with ninhydrin $0.2 \%$ in acetone and heating at $100^{\circ} \mathrm{C}$ for $3 \mathrm{~min}$.

\section{DNA composition}

$\mathrm{G}+\mathrm{C}$ mol \% content of DNA was determined by the American Type Culture Collection (Rockville, MD). The melting temperature was determined on a Gilford Spectrophotometer, and Escherichia coli strain B (Sigma D4 889) was used as a standard.

\section{Results}

\section{Growth and morphology}

Examination of toluidine blue-stained sections of infected genital hair by light microscopy with oil immersion revealed rods of coryneform morphology and yeast forms as shown in fig. 1. Direct plating of the suspension of macerated hair nodule on Casman's sheep blood agar yielded a mixed culture containing both Trichosporon beigelii and the gram-positive bacillus, and frequently no other organisms. All 14 strains had similar colonial morphology and growth characteristics. After incubation for $48 \mathrm{~h}$ at $35-37^{\circ} \mathrm{C}$ on Casman's sheep blood agar, colonies were 1-2 mm in diameter (fig. 2); maximum growth was achieved after incubation for 5 days when colonies were $3-5 \mathrm{~mm}$ in diameter, depending on the strain; $\beta$-haemolysis and an unpleasant odour were also noted at this time. Colonies were grey-cream in colour, opaque, raised with a bevelled margin and had a contoured glistening surface; the edges were crenated and the consistency was friable (fig. 3). The organisms were strict aerobes but were not fastidious, and could be cultured on nutrient agar and routine laboratory media. The characteristic colonial morphology and odour were more pronounced on blood agar. Optimum temperature for growth was $35-37^{\circ} \mathrm{C}$. Microscopically, after

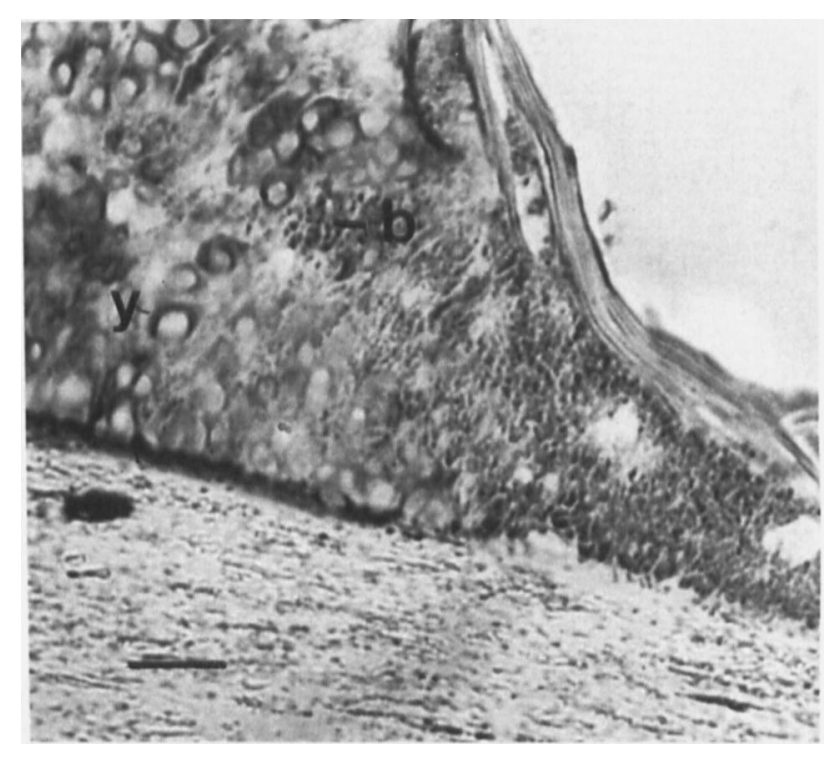

Fig. 1. Histological section of infected hair stained with toluidine blue showing yeast forms (Y) and bacteria (B). 


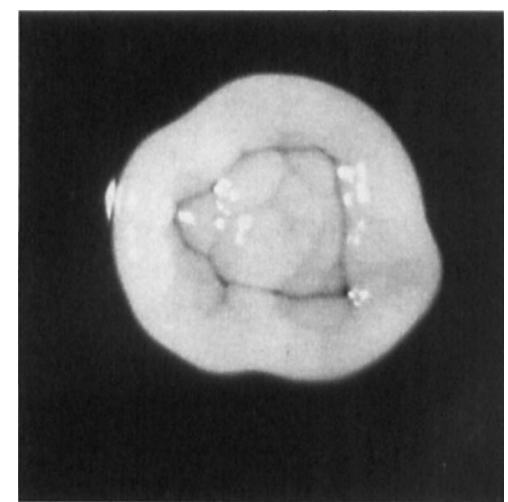

Fig. 2. A 48-h culture of a piedra isolate grown on Casman's sheep blood agar at $37^{\circ} \mathrm{C} ; \times 5.4$.

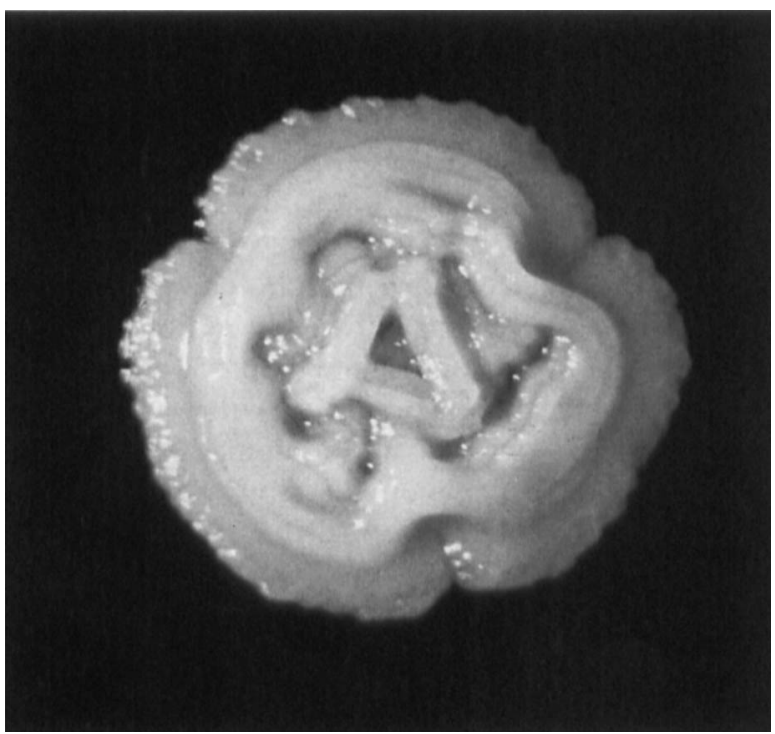

Fig. 3. A 4-day culture of a piedra isolate grown on Casman's sheep blood agar at $37^{\circ} \mathrm{C} ; \times 4 \cdot 7$. incubation for 4 days on Casman's sheep blood agar, the organisms were slender, more regular, grampositive, non-sporeforming, non-acid-fast bacilli that were non-motile with a tendency to clump.

\section{Rod-to-coccus cycle}

In a comparison of $B$. epidermidis and the unknown organism, in tests with three media and temperatures of 25,30 and $37^{\circ} \mathrm{C}$, B. epidermidis underwent complete transformation to coccal phase after $48 \mathrm{~h}$ on CYA at all three temperatures (fig. 4), whereas the piedra isolate became predominantly coccal on the same medium only after incubation for 2 weeks at $37^{\circ} \mathrm{C}$ (fig. 5). No coccal forms were seen on YMA and blood agar at either 25 or $30^{\circ} \mathrm{C}$. Although the new species would grow at $25^{\circ} \mathrm{C}$, it did so only poorly on media without blood. Under these conditions, two colony types were seen, a pinpoint colony and a larger smooth colony. Microscopic morphology was identical for each colony type and subculture of each produced the same two colony types.

\section{Biochemical characteristics}

The piedra isolates were catalase positive, oxidase negative and produced methanethiol. By conventional methods, the strains were asaccharolytic. Proteolytic activity was shown by conventional methods with casein, gelatin and litmus milk. DNA was hydrolysed. Of 14 tested strains, five utilised xanthine and two hydrolysed tyrosine. In addition, B. linens, B. epidermidis and the three piedra strains tested by API Rapid ANA gave positive results for hydrolysis of leucyl-glycine, glycine, proline, phenylalanine, arginine and serine, and negative results with other test substrates. All strains tolerated $\mathrm{NaCl} 6.5 \%$ but did not
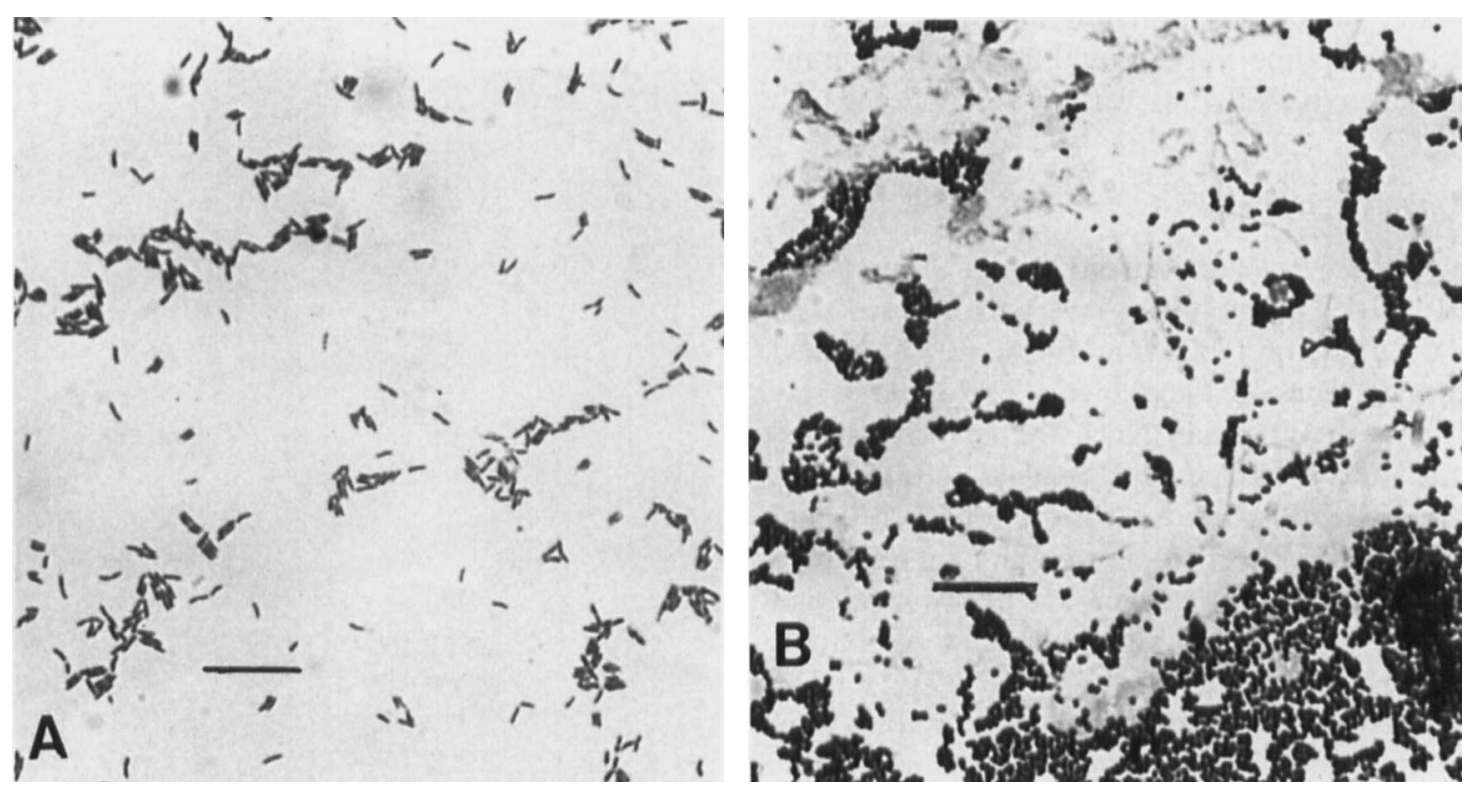

Fig. 4. Gram-stained of film the rod phase (A) from a 48 -h culture of B. epidermidis on Casman's sheep blood agar at $37^{\circ} \mathrm{C}$, and the coccal phase on CYA $(\mathbf{B}) ; \times 1000$. 

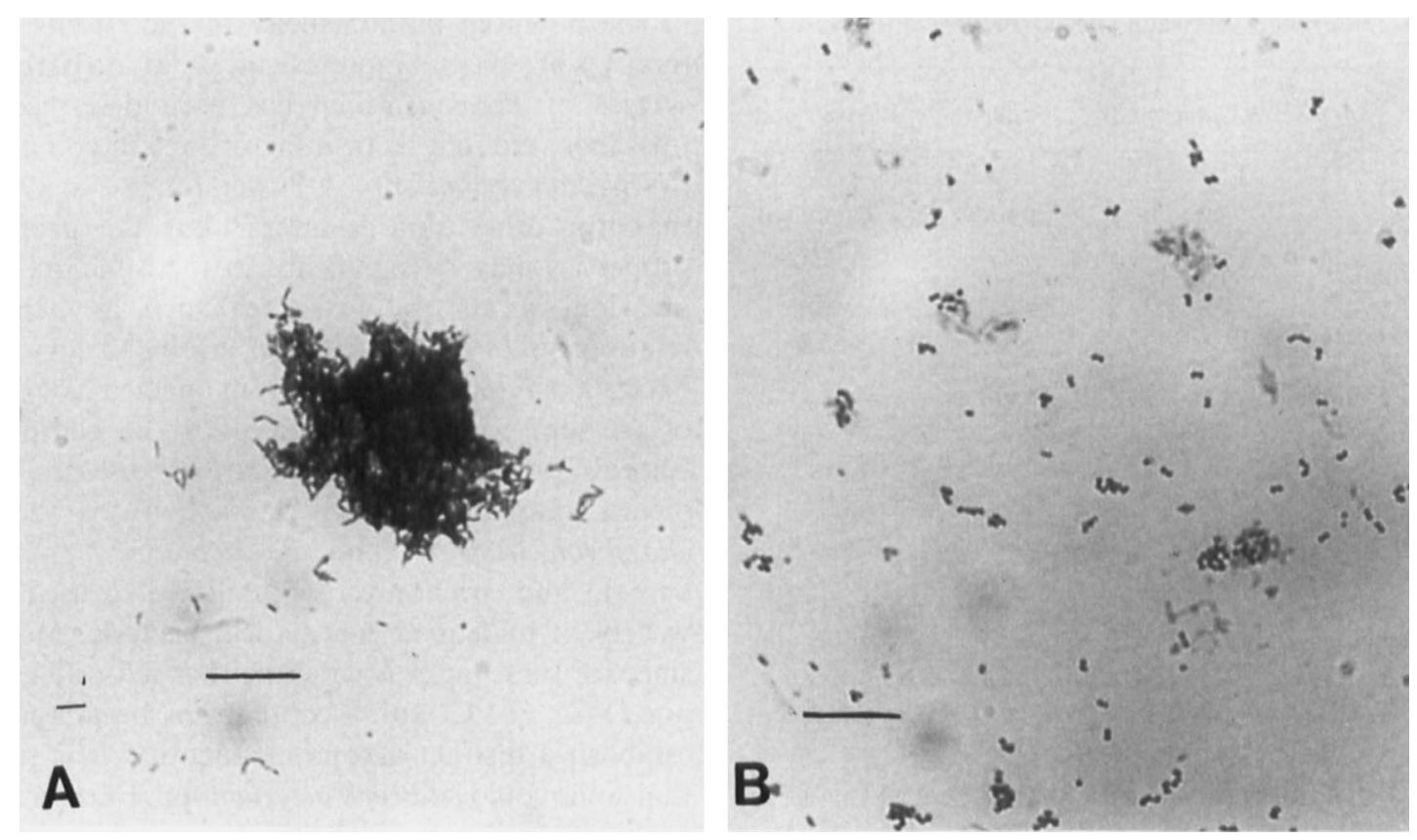

Fig. 5. Gram-stained film of the rod phase of a piedra isolate after incubation for 2 weeks at $37^{\circ} \mathrm{C}$ on $\mathrm{Casman}$ 's sheep blood agar (A), and the coccal phase after incubation for 2 weeks at $37^{\circ} \mathrm{C}$ on CYA $(\mathbf{B}) ; \times 1000$.

grow at higher concentrations. In contrast, $B$. epidermidis grew well on $\mathrm{NaCl} 10 \%$ but was partially inhibited at $15 \%$. Uniformly negative results were obtained in tests for: nitrate reduction; arginine, ornithine and lysine decarboxylation; hydrolysis of Tween 80 ; production of $\mathrm{H}_{2} \mathrm{~S}$, urease and indole; and growth on MacConkey agar.

\section{Antibiotic sensitivity}

All 14 strains of the new organism were uniformly sensitive to penicillin, ampicillin, vancomycin, trimethoprim sulphate and cephalothin; 10 strains were resistant to erythromycin, and six were resistant to oxacillin and tetracycline. Ergosan (Triclosan), the active agent used in many antibacterial soaps, inhibited all strains.

\section{Cell-wall analysis}

Meso-DAP and the sugars glucose, galactose, xylose and ribose were present in the cell walls. Mycolic acids and arabinose were not detected.

Table II. Fatty-acid composition* of Brevibacterium spp.

\begin{tabular}{l|rccccc}
\hline & \multicolumn{7}{|c}{ Percent of structural fatty acids } \\
\cline { 2 - 7 } Organisms & $\begin{array}{c}150: 0 \\
\text { iso }\end{array}$ & $\begin{array}{c}15: 0 \\
\text { Anteiso }\end{array}$ & $\begin{array}{c}16: 0 \\
\text { iso }\end{array}$ & $\begin{array}{c}16: 0 \\
\text { Anteiso }\end{array}$ & $\begin{array}{c}17: 0 \\
\text { iso }\end{array}$ & $\begin{array}{c}17: 0 \\
\text { Anteiso }\end{array}$ \\
\hline B. epidermidis & 8.56 & 57.82 & 3.59 & 0.93 & 1.08 & 26.68 \\
E2cr ${ }^{\mathrm{T}}=$ ATCC 49030 & 13.89 & 47.64 & 11.2 & 1.26 & 1.72 & 20.65 \\
E7s & 13.17 & 38.00 & $10 \cdot 31$ & 2.04 & 2.93 & 28.82 \\
$86-3$ & 16.12 & 52.65 & 7.92 & 1.04 & 1.64 & 18.42 \\
& & & & & & \\
\hline
\end{tabular}

* Only those representing $>2 \%$ are identified.

\section{Fatty-acid composition}

The major fatty acids present in three strains of the new organism and B. epidermidis are shown in table II. The major component in all organisms was anteiso 15:0 with anteiso 17:0 as the second component. Smaller percentages of iso $15: 0$ and iso $16: 0$ were present, although percentages were higher in the new organism than in B. epidermidis.

\section{DNA analysis}

The $\mathrm{G}+\mathrm{C}$ composition of strain E2cr was $63.05 \mathrm{~mol} \%$ which was within the range of values cited for other species of Brevibacterium.

The major similarities and differences between the new species and skin isolates of the genera Corynebacterium and Brevibacterium are shown in table III.

\section{Discussion}

Aerobic, non-sporeforming, gram-positive bacilli of environmental origin frequently evade a taxonomic position. In some studies of clinical isolates, in which classical methods alone were used, over half of the coryneforms were unnamed. ${ }^{5}$ The more analytical methods added information, but left many groups taxonomically unassigned. With the advent of wholecell fatty-acid analysis and the API Coryne system, many of the clinically relevant species, such as $C$. diphtheriae, C. jeikeium and C. cystitiditis (D2) can be identified reliably. ${ }^{\mathbf{1 6}-18}$

There are several morphologically similar genera from which medically significant coryneform isolates 
Table III. Differences between species of Brevibacterium

\begin{tabular}{|c|c|c|c|}
\hline Character & B. epidermidis & B. linens & Piedra isolates \\
\hline \multicolumn{4}{|l|}{ Morphology } \\
\hline colony & smooth & smooth & $\begin{array}{l}\text { contoured } \\
\text { friable }\end{array}$ \\
\hline -emusifiable & yes & yes & no \\
\hline $\begin{array}{l}\text { - time for } \\
\text { rod-to-coccus }\end{array}$ & $48 \mathrm{~h}$ & 6 days & 2 weeks \\
\hline -haemolytic & + & - & + \\
\hline Growth at $25^{\circ} \mathrm{C}$ & good & good & slow \\
\hline Growth at $37^{\circ} \mathrm{C}$ & good & poor & good \\
\hline Tellurite reduction & - & - & + \\
\hline Nitrate reduction* & + & + & - \\
\hline Pyrazinamidase* & - & + & - \\
\hline Mannose* & - & + & - \\
\hline Ribose* & - & - & + \\
\hline Xanthine utilisation* & + & + & $5 / 14$ \\
\hline Tyrosine hydrolysis & + & + & $2 / 14$ \\
\hline
\end{tabular}

* Results from API Coryne

must be distinguished. We have shown that these white piedra isolates are in the genus Brevibacterium by: rod-to-coccus cycle conversion; fatty-acid profile; the presence of DAP and absence of mycolic acids and arabinose in the cell wall; strict aerobic growth; $\mathrm{NaCl}$ tolerance; $\mathrm{G}+\mathrm{C} \mathrm{mol} \%$ content; production of methanethiol; strong proteolysis; and lack of saccharolytic activity in conventional tests.

The fatty-acid profiles of Corynebacterium spp. are predominantly straight chain saturated and monounsaturated, whereas the major component of the new organism is iso 15:0 with anteiso $17: 0$ as the second component. ${ }^{19}$ The DNA G $+\mathrm{C} \mathrm{mol} \%$ composition of strain E2cr was $63.05 \%$ which is similar to that of other species of Brevibacterium: B. epidermidis, $63.3 \% ; B$. linens, $63.4 \%$; and $B$. iodinum, $62.5 \%{ }^{20}$

Many environmental, poorly defined species were originally included in the genus Brevibacterium. With more exacting studies, many of these have now been re-assigned, such as $B$. divaricatum, which has mycolic acid and arabinose in the cell wall and was found to resemble $C$. glutamicum. Similarly, the fatty-acid components of $B$. acetylicum are incompatible with Brevibacterium spp. On the other hand, the unassigned CDC Gp.B resembles the genus Brevibacterium in its whole cell fatty-acid composition. ${ }^{17}$ Currently, in contrast with previous classifications, there are only four recognised species: $B$. linens, $B$. iodinum, $B$. case $i$ and $B$. epidermidis. ${ }^{21}$ The latter is the only species isolated from skin; the others have been associated with dairy products, have lower optimum temperature for growth, and are pigmented.

The white piedra isolate described here resembles $B$. epidermidis in habitat but differs from it in several significant ways (table III). The colonial and microscopic morphology are distinctive and the cultural conditions necessary to initiate the rod-to-coccus cycle are different. Biochemically, the new species can reduce tellurite and utilise ribose. We propose a new species, B. mcbrellneri, and the type strain, E2cr, has been deposited with the ATCC (49030).
The potential pathogenicity of the strains in this report is of particular interest, as, so far, no pathogenic species of Brevibacterium has been described. Salt tolerance, thought to be a factor in skin colonisation by Brevibacterium spp., is lower for the new strains than for other skin isolates, ${ }^{22}$ but the proteolytic properties may be significant in the attachment and invasion of keratin structures such as hair. The relationship of the white piedra strains to coryneform bacteria previously cultured from infected hair of cases of trichomycosis axillaris needs to be clarified..$^{23-25}$ Ellner ${ }^{2}$ postulated two separate diseases-white piedra, caused by the synergic activity between Trichosporon beigelii and B. mcbrellneri (proposed name), and trichomycosis axillaris, caused by a variety of undefined coryneform bacteria. However, since for these latter isolates, neither cell-wall analysis nor DNA $\mathrm{G}+\mathrm{C} \mathrm{mol} \%$ content has been studied to establish a distinct taxonomic identity, it is possible that some could be Brevibacterium spp. Further studies are necessary to elucidate the taxonomic position of isolates from trichomycosis axillaris to evaluate the pathogenic potential of Brevibacterium spp. for skin and hair.

Fatty-acid analysis was done by Microbiological ID Incorporated (MIDI) and helpful discussion with Dr M. Sasser is gratefully acknowledged. Technical assistance was provided by Jeannette Gerguis. We also thank Dr C. Greenberg for photomicrographs and Deborah Gossett for preparation of the manuscript.

\section{References}

1. Kalter DC, Tschen JA, Cernoch PL et al. Genital white piedra: epidemiology, microbiology and therapy. $J$ Am Acad Dermatol 1986; 14: 982-993.

2. Ellner KM, McBride ME, Kalter DC, Tschen JA, Wolf JE. White piedra: evidence for a synergistic infection. $\mathrm{Br} J$ Dermatol 1990; 123 : 355-363.

3. Goodfellow M, Minnikin DF (eds). Chemical methods in bacterial systematics. Orlando, Academic Press. 1985.

4. Jones D, Collins MD. Irregular, non-sporing gram-positive rods. In: Sneath PHA (ed) Bergey's Manual of systematic bacteriology, vol II. Baltimore, Williams and Wilkins. 1986: $1261-1434$

5. Clarridge JE. When, and to what extent should coryneform bacteria be identified? Clin Microbiol Newsletter 1986; 8: $32-34$.

6. Pitcher DG, Malnick H. Identification of Brevibacterium from clinical sources. J Clin Pathol 1984; 13: 1395-1398.

7. Jones, D, Keddie RM. Genus Brevibacterium Breed 1953. In: Sneath PHA (ed) Bergey's Manual of systematic bacteriology, vol II. Baltimore, Williams and Wilkins. 1986: 1301-1313.

8. Hendrickson DA. Reagents and strains. In: Lennette EH, Balows A, Hausler WJ et al. (eds) Manual of clinical microbiology, 4th edn. Washington, D.C., American Society for Microbiology. 1985: 1093-1107.

9. Phillips E, Nash P. Culture media. In: Lennette EH, Balows A, Hausler WJ et al. (eds) Manual of clinical microbiology, 4th edn. Washington, D.C., American Society for Microbiology. 1985: 1051-1092.

10. Webster GF, McGinley KJ. Use of litmus milk agar for presumptive identification of cutaneous propionibacteria. J Clin Microbiol 1977; 5: 661-662.

11. Bauer AW, Kirby WMM, Sherris JC et al. Antibiotic susceptibility testing by a standardized single disk method. Am J Clin Pathol 1966; 45: 493-496. 
12. Kuykendall LD, Roy MA, O'Neill JJ et al. Fatty acids, antibiotic resistance, and deoxyribonucleic acid homology groups of Bradyrhizobium japonicum. Int J Syst Bacteriol 1988; 38: 358-361.

13. Minikin DE, Ashamaony L, Goodfellow M. Differentiation of Mycobacterium, Nocardia, and related taxa by thin-layer chromatographic analysis of whole-organism methanolysates. J Gen Microbiol 1975; 88: 200-204.

14. Goodfellow M, Collins MD, Minnikin DE. Thin-layer chromatographic analysis of mycolic acid and other long-chain components in whole-organism methanolysates of coryneform and related taxa. J Gen Microbiol 1976; 96: 351-358

15. Staneck JL, Roberts GD. Simplified approach to identification of aerobic actinomycetes by thin-layer chromatography. Appl Microbiol 1974; 28: 226-231.

16. Freney J, Duperron MT, Courtier C et al. Evaluation of API Coryne in comparison with conventional methods for identifying coryneform bacteria. J Clin Microbiol 1991 ; 29 : $38-41$.

17. Bernard KA, Bellefeuille M, Ewan EP. Cellular fatty acid composition as an adjunct to the identification of asporogenous, aerobic gram positive rods. J Clin Microbiol 1991; 29: 83-89.

18. Gavin SE, Leonard RB, Briselden AM et al. Evaluation of the Rapid CORYNE identification system for Coryne- bacterium species and other coryneforms. J Clin Microbiol 1992; 30: 1692-1695.

19. Collins MD, Cummins CS. Genus Corynebacterium Lehmann and Neumann 1896. In: Sneath PHA (ed) Bergey's Manual of systematic bacteriology, vol II. Baltimore, Williams and Wilkins. 1986: 1266-1276.

20. Collins MD, Farrow JAE, Goodfellow M et al. Brevibacterium casei sp. nov. and Brevibacterium epidermidis sp. nov. Syst Appl Microbiol 1983; 4: 388-395.

21. Collins MD. The Genus Brevibacterium. In: Balows A, Trüper HG, Dworkin M et al. (eds) The prokaryotes, vol II, 2nd edn. New York, London, Springer-Verlag. 1991: 1351-1354.

22. Sharpe ME, Law BA, Phillips BA et al. Methanethiol production by coryneform bacteria: strains from dairy and human skin sources and Brevibacterium linens. J Gen Microbiol 1977; 101 : 345-349.

23. Crissey JT, Rebell GC, Laskas JJ. Studies on the causative organism of trichomycosis axillaris. $J$ Invest Dermatol $1952 ; 19: 187-197$.

24. McBride ME, Freeman RG, Knox JM. The bacteriology of trichomycosis axillaris. Br J Dermatol $1968 ; 80: 509-513$.

25. Savin JA, Somerville DA, Noble WC. The bacterial flora of trichomycosis axillaris. J Med Microbiol 1970; 3: 352-356. 